\title{
CAMPING TOURISM: A REVIEW OF RECENT INTERNATIONAL SCHOLARSHIP
}

\author{
Christian M. ROGERSON \\ School of Tourism \& Hospitality, College of Business and Economics, University \\ of Johannesburg, Bunting Road, Johannesburg, South Africa, e-mail: chrismr@uj.ac.za \\ Jayne M. ROGERSON* \\ School of Tourism \& Hospitality, College of Business and Economics, University \\ of Johannesburg, Bunting Road, Johannesburg, South Africa, e-mail: jayner@uj.ac.za
}

\begin{abstract}
Citation: Rogerson C.M. \& Rogerson J.M. (2020). CAMPING TOURISM: A REVIEW OF RECENT INTERNATIONAL SCHOLARSHIP. GeoJournal of Tourism and Geosites, 28(1), 349359. https://doi.org/10.30892/gtg.28127-474
\end{abstract}

\begin{abstract}
One of the most under-researched facets of lodging is that which surrounds the niche of camping tourism. This review article traces trends and recent developments shaping international research on camping tourism. The analysis begins with a discussion of definitional and conceptual issues. Thereafter, the international spread of camping tourism as well as its local impacts for destinations is interrogated. The marginal role of camping in overall tourism studies scholarship is isolated. Key themes of concern in recent research are, inter alia, demand-side considerations; supply-side research; a distinctive scholarship on holiday camps and low-budget tourism; and, new innovations and management challenges which are associated with the changing character of camping tourism in many parts of the world. Knowledge gaps are identified in literature both in terms of the geography and thematic foci of camping tourism literature. Among knowledge gaps are the supply-side evolution of camping tourism, the role of private sector entrepreneurs, local development impacts and planning, and innovative management interventions for the sustainable development of camping tourism.
\end{abstract}

Key words: camping tourism; caravan parks; innovation; sustainable management; research review

\section{INTRODUCTION}

Camping tourism is a global phenomenon which is rising in significance and at the same time is experiencing considerable changes in its complexion. This review article traces trends and recent developments impacting the broad research field which is styled as 'camping tourism'. Arguably, whilst camping tourism research has expanded in recent years it still remains one of the 'poor cousins' of international tourism scholarship. This said, a search in Google Scholar and Scopus of relevant terms such as 'camping', 'caravan parks'

\footnotetext{
* Corresponding author
} 
and 'recreational vehicles' discloses an emerging body of research across several countries and with different thematic foci. In particular, it can be observed there has been an upturn of research around camping tourism which has occurred since the appearance in 2013 and 2014 of two influential review papers by Brooker \& Joppe (2013, 2014). This survey of the 'state of the art' of literature on camping tourism builds upon the foundations provided by these authors. The paper is informed by the viewpoint that "a review of past research efforts is an important endeavour in all academic research areas" (Nunkoo et al., 2013: 5). In particular, among several advantages of the pursuit of review articles are the identification of knowledge gaps where additional research might be useful as well as potentially to facilitate theoretical advances. In unpacking major international debates in the development of scholarship around camping tourism two sections of material are provided. In the first part the analysis begins with a discussion of definitional and conceptual issues.

Thereafter, the international spread of camping tourism as well as its local impacts for destinations is interrogated. The marginal role of camping in overall tourism studies scholarship is highlighted. In the second part of the article the focus turns to an overview of several key research foci that can be isolated in extant writings. Themes of concern are, inter alia, demand-side considerations; supply-side research; a distinctive scholarship on holiday camps and low-budget tourism; and, new innovations and management challenges which are associated with the changing character of camping tourism in many parts of the world.

\section{INTERNATIONAL DEBATES}

\section{Definition and Conceptual Issues}

Over several centuries Ward \& Hardy (1986: 2) draw attention to the fact that "the word camp had a purely military connotation: the temporary accommodation of armies in the field using tents and portable huts". The term's meaning evolved gradually to cover also the improvised short-term settlements of various groups such as migratory farm workers, nomads, gypsies, explorers and refugees. Protest camps represent another manifestation of short-term temporary settlements undertaken often with tents and portable huts (Feigenbaum et al., 2013). In its most extreme form the 'non-recreational camp' connotes detainment and incarceration. As pointed out by Collins \& Kearns (2010: 59) "the prefix 'concentration' surely signals the grimmest incarnation of 'camping”". Arguably, therefore, the activity of 'camping' initially became an inevitable accompaniment to human activities at locations where permanent buildings were either unavailable or deliberately not provided for shelter. Historically, therefore, much of the phenomenon of camping "was a necessary evil, not an activity undertaken for its own sake" and significantly it "was a penance not a pleasure" (Ward \& Hardy, 1986: 2). Collins et al. (2020: 21) point out that the verb 'camping' and its term 'camp' as a code for spaces of mobile dwelling "occupy ambivalent territory". For the affluent and well-housed groups camping can be a space and time of recreational discretion whereas for those vulnerable, less fortunate and living precariously, the camp as a form of 'informal housing' might offer temporary respite from forced and continual mobility (Kearns et al., 2019; Collins et al., 2020). Historically, in terms of recreation and tourism Blichfeldt \& Mikkelsen (2013) assert that originally camping was defined as staying in a tent in nature as a low-cost form of accommodation when on holiday.

For Brooker \& Joppe (2014: 335) camping, however, "has matured beyond its origins as an inexpensive, temporary sojourn in a rural environment, evolving into a highly fragmented niche tourism sector". Its definition is contested now with 'traditionalists' simply equating it with tents and outdoor recreation. Nevertheless, for an increasing number of campers this view is changing as the activity "involves sleeping at least one night in a recreational vehicle (RV), caravan, cabin or other type of temporary shelter where the comforts of home can be enjoyed" (Brooker \& Joppe 2014: 335). This aligns camping with 
the phenomenon of 'drive tourism' which enables the bringing of a home in the form of a diverse range of recreational vehicles, including caravans (Prideaux \& McClymont, 2006; Van Heerden, 2010a; Østby, 2013; Blichfeldt \& Mikkelsen, 2014; Prideaux, 2020).

Patterson et al. (2015) style caravanning tourism as a special form of tourism with the caravan as part of both tourism transportation as well as accommodation. Caravanning is thus to be understood also as a subset of drive tourism as well as a component of wider recreational experiences that involve hospitality outdoors (Van Heerden, 2010a; Caldicott, 2011; Brooker \& Joppe, 2013; Lashley, 2015). For Doğantan \& Emir (2019) caravan tourism is associated with strong linkages to nature-based tourism. In seeking to conceptualize camping as a whole Collins \& Kearns (2010: 59) start from the proposition that "if all inclusive resorts and luxury hotels are one end of the tourism accommodation spectrum, then campgrounds surely lie at the other". Beyond cost and amenity-related considerations, camp grounds and caravan parks are seen as distinctive forms of accommodation in two major respects. The actual accommodation (caravan or tent) "is generally owned by the user, hence what is paid for is just short-term rental on the site that includes access to a range of (traditionally rudimentary) ancillary services” (Collins \& Kearns, 2010: 59).

Further, in some instances, "the same holidaymakers who on one occasion might stay in hotels or resorts, on another opt to stay in campgrounds" (Collins \& Kearns, 2010: 59). In turn this means that "the privations incurred through access to only basic facilities and exposure to the elements are, generally, a matter of choice rather than necessity" (Collins \& Kearns, 2010: 59). Accordingly, 'camping' must be understood as "a holistic activity and accommodation choice” (Brooker \& Joppe, 2014: 335). For Crabeck (2013) camping is a shadowy element of the lodging sector with particular difficulties in terms of its enumeration. It encompasses an array of activities from basic camping to luxury RVs as well as upmarket cabins, and most recently the growth of 'glamping'. Arguably, over the past decade "camping has been experiencing a transformation through the implementation of a novel and innovative accommodation increasingly referred to as glamping" (Hrgović et al., 2019: 773). The latter - a recent innovation in creative accommodation - derives from the words glamour and camping and is attracting mounting interest (Cvelić-Bonifačić et al., 2017; Lee et al., 2019). Brochado \& Perreira (2017: 77) view it is "an emergent concept in camping that combines comfort with direct contact with nature". Hrgovic et al. (2019) assert that glamping is an umbrella term for numerous types of accommodation provision. It most often takes the form of tents but can also include other innovative types of luxury accommodation such as yurts or treehouses (Hrgović et al., 2018). As a whole Brooker \& Joppe (2013: 1) characterise the outdoor hospitality sector as including caravan parks, camping grounds and glamping and observe that it "has emerged from a low-cost tourist niche to a mainstream versatile recreation experience valued at different levels by different segments".

\section{International Expansion and Destination Impacts}

The phenomenon of recreational camping - in its various manifestations - is observed throughout the world, albeit is viewed as particularly popular in the tourism economies of North America (Stephens et al., 1989; Janiskee, 1990; Timothy \& Teye, 2009; Brooker \& Joppe, 2014; Young, 2017), Australia (Caldicott et al., 2014) and New Zealand (Collins \& Kearns, 2010; Collins et al., 2018). Its popularity is further recorded in several countries of Europe including Croatia (Grzinic et al., 2010; Cerovič, 2014), Denmark (Mikkelsen \& Blichfeldt, 2015), Germany (Doğantan \& Emir, 2019), Spain (Garcia-Pozo et al., 2011; Salo et al., 2020), Turkey (Doğantan et al., 2017) and United Kingdom (Rees Pryce, 1967; Prentice \& Witt, 1991; Lashley, 2015). This said, in many destinations camping is weather-sensitive and a highly seasonal phenomenon (Collins \& Kearns, 2010; Triantafillidou \& Siomkos, 2013; Hewer et al., 2015; Lashley, 2015). According to Cerović (2014: 57) camping "is an important economic branch in Europe which generates nearly 
400 million overnights and which makes up the majority of accommodation units in some countries". In the USA recent estimates are of approximately 16 ooo campgrounds with just over half privately owned and operated the remainder being public-agency campgrounds (Timothy \& Teye, 2009). In Australia caravan parks are the second highest provider of domestic tourism accommodation (Caldicott, 2011) and the subsector provides at least half of the country's national tourism bed capacity (Caldicott \& Scherrer, 2013a). South Africa is noted as another significant focus for the camping sector (Van Heerden, 2008, 2010a, 2010b, 2020). Other destinations where camping has attracted some academic concern include Indonesia (Budiasa et al., 2019), Iraq (Al-Zahawai et al., 2019), Mexico (Jimenez \& Martinez, 2017), and Sri Lanka (Jayakody, 2019). It is considered that across the international context the economic effects of camping tourism "have been steadily increasing over the past few years, given the fact that camping is transforming from a niche to a mainstream-tourism product” (Mikulić et al., 2017: 227). In several countries, such as Australia, New Zealand or South Africa, the geography of camping and of caravanning is closely tied to coastal areas and coastal tourism (Collins \& Kearns, 2010; Doğantan \& Gülenç, 2017; Rogerson \& Rogerson, 2019, 2020). In others, such as the USA, however, a focus on nature tourism and protected areas means that non-coastal areas assume significance in the overall spatial distribution of camping tourism (Timothy \& Teye, 2009).

\section{The Poor Cousin of Tourism Research}

Despite its widespread occurrence and significant economic contribution across several destinations Rice et al. (2019: 424) aver that as "compared to other sectors of the tourism industry, camping is relatively under-researched”. For Brooker \& Joppe (2013: 1) it "has received minimal attention in the literature". The deficit in academic research about camping is underscored also by several other scholars (Prideaux \& McClymont, 2006; Mikulić et al., 2017). Most recently, Van Rooij \& Margaryan (2020: 3) observe that despite its significance as a growing form of outdoor recreation "camping has received minimal attention in the research literature". Lashley (2015: 121) maintains that "the amount of research undertaken with the specific intention of exploring caravanning and caravaners is limited”. Likewise, Mikkelsen \& Cohen (2015) assert that caravanning is a relatively neglected topic in tourism scholarship. Overall, the activity of camping and caravanning is one of the least well-researched of different lodging forms as is shown through the findings of the recent bibliometric analysis produced by Okumus et al. (2019). One potential reason for its under-researched character is caravanning often is considered only as "a mundane type of holidaymaking" (Mikkelsen \& Blichfeldt, 2015: 252). Caldicott (2011: 10) writes of its representation of "ordinary and routine practices" and suggests its lack of attention relative to other forms of leisure is accounted for by its "fragmented" character.

Lashley (2015: 115) states that when caravanners go on holiday they can be likened to snails "in that they carry their 'homes' with them". This said, caravan parks offer a range of accommodation options from basic to resort standard and can include in some countries short-term as well as permanent sites (Gilbert, 2013). Caldicott et al. (2018) argue that the caravan park, as a subsector of tourism accommodation services, has been viewed as the traditional symbol of caravanning. But, that the focus in some countries - particularly Australia and New Zealand - is shifting now more on the caravan itself and its serviceability as a long-term, touring residential home as opposed to a temporary short-term holiday unit to be conveniently parked in a caravan park (Caldicott et al., 2014; Collins et al., 2018).

\section{CONTEMPORARY RESEARCH THEMES}

\section{Demand-Side Issues}

The existing international scholarship on camping and caravanning is dominated

by demand-side investigations variously of the demographics, motivations and 
satisfaction of participants with choices of particular camp sites (Stephens et al., 1989; Prideaux \& McClymont, 2006; Van Heerden, 2010b; Park et al., 2010; O’Neill et al., 2011; Østby, 2013, Brooker \& Joppe, 2014; Brochardo \& Pereira, 2017; Mikulić et al., 2017; Van Heerden, 2020). Demographically whilst camping is viewed as appealing to all age cohorts (with the exception of 18-24 years) it is seen as particularly popular with young families (Brooker \& Joppe, 2013; Mikkelsen \& Blichfeldt, 2015). From Spain there is evidence that, as compared to other accommodation types, camp site tourism is less sensitive to congestion. Indeed, whilst campers can be sensitive to overcrowded locations, a crowded atmosphere can be accepted if embedded in an attractive social environment and thus towards a positive social experience from camping (Salo et al., 2020). In Denmark caravan sites are viewed as 'safe places' that allow children to experience independence and afford an opportunity for children to do things on their own (Mikkelsen \& Blichfeldt, 2015). Danish camping sites mostly are visited by both extended and nuclear families (Blichfeldt \& Mikkelsen, 2013). In Australia, however, Prideaux \& McClymont (2006: 57) discern a notable "shift from family to retired and empty nester caravanning". The travels of 'grey nomads' have been the focus of considerable investigation in Australian research (Holloway et al., 2011; Patterson et al., 2015).

Distinctions are drawn between different market segments of campers such as participants that use static (or rarely moved) holiday caravans as opposed to the group of mobile or touring caravans (Lashley, 2015; O'Dell, 2015). The most important differentiation is between the short-term segment and those full-timers who live permanently or semi-permanently in their caravan or RV (Lashley, 2015). Gilbert (2013) points out that caravan parks span the void between the sectors of tourism and housing. Further, in Australia, the United Kingdom and New Zealand they have been providing accommodation options for groups at risk of homelessness (Nelson \& Minnery, 2008; Brooker \& Joppe, 2013; Gilbert, 2013; Kearns et al., 2019; Collins et al., 2020). In the case of Belgium the residential function of caravan parks is now more important than that for leisure travellers (Crabeck, 2013). The deep historical roots of many Americans with being outdoors and their association with open spaces has been documented in a number of studies (Garst et al., 2010; Kambic, 2018). An early study into the growth of recreational vehicles in the USA revealed that "the RV life style is characterized by a strong desire to experience the outdoors and socialize with other campers while still retaining the comforts and convenience of a familiar domicile" (Green, 1978: 429). In New Zealand Collins \& Kearns (2010) suggest that campgrounds represent "therapeutic landscapes" to the extent that they facilitate literal proximity to areas of natural beauty and a strong sense of being 'in' nature and correspondingly away from the stresses of urban environments. Campers embrace selfimposed simplicity and can break away from normal routines and distance themselves physically and psychologically from urban living and enjoy a sense of community in many campgrounds (Collins \& Kearns, 2010; Lashley, 2015). The social benefits of camping as family holidays can be significant allowing families and friends to spend quality time together in natural settings (Timothy \& Teye, 2009; Mikkelsen \& Blichfeldt, 2018). Brooker \& Joppe (2014: 336) write of the personal rewards and liminal experience which "provides individuals with opportunities to reconnect with simpler living practices, natural environments and with themselves, family and friends". For others, however, budgetary considerations are paramount as camping is usually less expensive than other forms of lodging (Timothy \& Teye, 2009). In addition, Lashley (2015) draws attention to caravanning and camping holidays as an affordable option during hard economic times in Europe.

\section{Supply-side Considerations}

The supply-side of camping and caravanning was relatively uncharted academic territory until recent years (Caldicott, 2011). Private sector entrepreneurship is a 
particularly neglected theme with extant research pointing to a significant role for lifestyle entrepreneurs (Van Rooij \& Margaryan, 2020). In the USA Timothy \& Teye (2009) stress the different roles assumed in the supply of facilities by the public and private sector.

Although private campgrounds account for 53 percent of facilities they account for three-quarters of US demand as public agency campgrounds are not as commercialized and instead are subsidized by governments and viewed as non-profit or self-sustaining enterprises with few amenities on offer. Some of the most recent innovative supply-side research has emerged out of Australia and New Zealand. In Australia Caldicott (2011) examines the parallel development of the caravan manufacturing sector and of the caravan park sector. The life cycle of caravan parks in Australia has been analysed within the framework of Butler's classic tourism area life cycle model. Using historical data it is shown that the pattern of caravan park development and evolution conforms to the involvement, exploration, development, consolidation and stagnation stages of the model (Caldicott \& Scherrer, 2013a). In the cases of Australia and New Zealand the development of these caravan parks was undertaken both under the aegis of the public sector as well as by private entrepreneurs (Collins \& Kearns, 2010; Caldicott, 2011). Beginning from rudimentary sites caravan parks were upgraded as caravanners demanded an array of improved amenities.

The historical experiences of Australia and New Zealand confirms the assertion of Simeoni \& Cassia (2019) that the makers of caravans are 'co-creators' of the tourism experience of caravanning. The period of the mid-1970s is described as "the glory days" of the caravan sector in Australia (Caldicott \& Scherer, 2013b: 117). A progressive downturn began in the numbers of caravan park sites and capacity engineered "through the closure of parks in favour of higher economic yielding development scenarios" (Caldicott, 2011:5).

As explained by Prideaux \& McClymont (2006) this demise of caravan parks was driven mainly by a conversion in coastal areas of beachfront land to high rise units and hotels. According to Gilbert (2013) while the redevelopment of low impact caravan sites into higher uses creates economic benefits at the same time there are negative ramifications for low cost family holidays as well as longer term impacts for the supply of affordable accommodation in coastal areas of Australia. With the reinvention of 'camping' in terms of improved quality accommodation and other facilities there is a recent wave of resurgence in caravanning as a component of drive tourism as reflected in an upturn in registrations of new campervans and motor homes (Caldicott \& Scherrer, 2013b). For many caravan parks in Australia and New Zealand a tipping point emerges with the potential for either closure and redevelopment or rejuvenation and transformation (Collins \& Kearns, 2010; Caldicott \& Scherrer, 2013b). Indeed, caravan/campgrounds in both Australia and New Zealand have a precarious and uncertain foothold in urban space as with escalating land prices they are sought after spaces for property redevelopment (Bunce, 2010; Collins et al., 2020).

\section{Holiday Camps and Low-Budget Tourism}

The historical development of organised holiday camps in which the activity of 'camping' takes place in purpose-built 'luxury' chalets is a further supply-side theme of note. The British experience is documented in the seminal works by Dawson (2007) and Ward \& Hardy (1986). Dawson (2007) attributes the growth of commercial holiday camps to the successful conclusion of a 20-year campaign with the passage of the Holidays With Pay Act in 1938. The final legislation recommended one week's annual paid vacation for all full-time workers and thus created a market for mass pleasure sites for ordinary working people and their families in Britain. The building of holiday camps was a solution to addressing what was at the time a crisis in terms of the limited affordable leisure options for working-class consumers (Dawson, 2007). According to Ward \& Hardy (1986: 22) the first holiday camp entrepreneur was not Billy Butlin but one Joseph Cunningham who started in 1908 for the 'working lads' of Liverpool a holiday camp on the Isle of Man which "provided cheap 
accommodation on a massive scale, but instead of chalets, the campers slept in row upon row of candle-lit tents". By 1938 there were approximately 200 small holiday camps in Britain variously organized by commercial enterprises, unions and political groupings; some were tents in the field whilst others had barrack-like accommodation (Dawson, 2007).

The two new chains of holiday camps that emerged in the 1930 s by Butlin and Warner marked a major change in terms of their size, facilities and organization (Dawson, 2011). Aimed at the emerging mass market the first Butlins camp opened at Skegness in 1936 (Ward \& Hardy, 1986). As argued by Dawson (2007: 300) the chain of camps launched by Butlin and Warner "provided all the entertainment, activities and amenities, necessary for a healthy and restful vacation in cheerful surroundings for an inexpensive allinclusive price". The holiday camps built by Warner and Butlin were initiatives for "packaging leisure' and a response to the perceived demand for low-cost all-inclusive holidays (Middleton, 2010; Dawson, 2011). Overall, these sites of organized pleasure "built on earlier ideas of all-inclusive camping holidays and developed more comfortable accommodation for the emergent working-class family market (Dawson, 2007: 303). By the 1970s Goodall (1987: 95) observes that the British holiday camps were past their prime and heading on a downhill trajectory as a consequence of competition both from a growing sector of selfcatering accommodation as well the rise of cheap 'Sun-Med' packages. Nevertheless, the enduring legacy of these holiday camps and their entrepreneurs is evidenced by several proposals which have emerged since 2013 for the establishment of low-cost resorts to be developed in South Africa based upon the Butlin's model as affordable holiday options for 'ordinary' families (Ensor, 2013; Mthente Research and Consulting Services, 2013). The proposal was to re-develop underused state properties such as disused municipal caravan parks into budget tourist facilities and thereby boost local demand for domestic affordable holidays most especially for the less affluent Black holiday-maker (Rogerson, 2015).

\section{New Innovations and Management Challenges}

As argued by Milohnić et al. (2019: 457) in the 21st century camping "is strongly marked by new trends in the development of accommodation at camp sites, foremost by new demand that combines wishing to stay outdoors and wanting all the comforts of home". The key drivers of change in Europe are that for certain groups camping becomes a lifestyle choice by guests who opt for camping accommodation not out of personal constraints but out of conviction and perceived need. The influence of glamping is seen as considerable and most especially in the United Kingdom (Cerović, 2014; Brochado \& Pereira, 2017) and Croatia (Hrgović et al., 2019). According to Brooker \& Joppe (2013: 4) glamping removes camping's negative attributes and whilst contributing to increased profitability and occupancy "glamping represents a transition from outdoor to indoor hospitality". It rejuvenates and redesigns the product of camping bringing together "in symbiosis the hotel industry and camping" (Hrgović et al., 2018: 622) This trend for "neocomfort' is "contributing to the renewed interest of tourists for camping" and offering managers of campsites an opportunity for an "extreme makeover" (Cerović, 2014: 57).

It is maintained that the "popularity of glamping, particularly among the younger generations, is driving the overall transformation of classical camping into glamping with numerous implications for the general competitiveness of the sector" (Milohnić et al., 2019: 457). No longer is camping the stereotype of "poor man's tourism"; glamping which is a specific kind of camping neutralizes its drawbacks through the provision of a high level of comfort (Sakacova, 2013; Petrusa \& Vlahov, 2019; Liberato et al., 2020). For Ketter (2020) the rise of glamping is one response to the demands of (especially European) Millennial travellers and their reshaping of the hospitality sector. For Bigné \& Decrop (2019) glamping illustrates one of the (many) paradoxes of postmodern tourists in terms of living 'more authentic experiences' which are closer to nature but in comfortable conditions. In the 
wake of radical changes that are internationally impacting the camping sector and caravan parks a critical supply-side research focus is that of the innovative management of these sites (Lucivero, 2012; Cvelić-Bonifačić et al., 2017; Brochado \& Brochado, 2019; Milohnić et al., 2019). In a useful contribution Blichfeldt (2009) chronicles the case of one specific caravan enterprise in Denmark as a focus for innovation and entrepreneurship in terms of the diversification of product offerings introduced at the case site. Within the fluid environment of the changing character of 'camping' it is argued there is a need for developing competitive management strategies for traditional camping grounds and caravan parks. One useful step is the introduction of integrated reporting as a framework for an upgraded approach for benchmarking for competitiveness (Persic et al., 2017).

Another aspect of management strategy is competitive pricing and revenue management as is shown by Poldrugovac et al. (2019). The sustainable management of campsites is an issue of increasing research attention (Timothy \& Teye, 2009; Del Moretto et al., 2017). Gračan \& Birin (2013) stress the significance of implementing ecological standards in the sustainable development of camping localities. Sustainable camp site management and the certification of camp sites is further explored by Milohnic \& CvelićBonifačić (2015). From the experience of Croatia, one of the major camping destinations in Europe, it is stressed that "innovative camping management is expected to manage changes of the camping product by embracing a quality mix of accommodation units and introducing innovative forms of camping accommodation" (Cerović, 2014: 56). Given the financial crises experienced in several European countries combined with rising travel costs there is an emerging segment of consumers who are demanding "alternative systems of camping accommodation, whereby camping equipment is no longer bought but rented in the campsite itself" (Cerović, 2014: 57). The required management shifts are thus both to address the market segments of those seeking low-cost leisure options as well as lifestyle campers with a demand "for comfortable stays in a natural environment, and the desire to spend time in well-kept dream resorts that are technologically advanced at the same time" (Cvelic-Bonifačić et al., 2017: 102). Overall, across several areas of Europe the response has been product innovation with the transformation of traditional campsites into "holiday parks" or "camping resorts" sometimes with a mix of offerings (Prentice \& Witt, 1991).

\section{CONCLUSION}

It has been observed recently that camping and caravan parks are "a rather neglected element of the tourism and hospitality industry" (Mikulic et al., 2017: 226). Nevertheless, there has been a welcome upturn in academic interest particularly over the past decade. This rise in scholarly concern has been boosted both by the sustained popularity of camping tourism as a form of outdoor hospitality as well as by significant changes in the complexion of this tourism segment. In common with trends in international tourism scholarship as a whole the balance of academic research on camping tourism currently is dominated by studies conducted in the global North. This points to one knowledge gap about camping tourism, namely its manifestation and development in the global South; at present there appears an emergent literature in the case of South Africa. The observed shifts occurring in camping tourism away from its traditional low-budget character signal several issues for a future research agenda. Demand-side investigations merit further attention in relation to the distinctive demographics, motives and satisfaction of participants with camp sites and caravan parks. In addition, the less developed supply side of camping tourism requires greater scholarly scrutiny, including through the pursuit of historical investigations about the evolution of camping tourism. The shifting role of private entrepreneurs as well as of the state in the sector's unfolding development is little explored. Of policy concern is the nexus of camping tourism with local economic development and the implications for local tourism planning and destination development. Finally, there is a 
critical cluster of research issues surrounding innovation and camping tourism, including around the sustainable management of camp sites or caravan parks.

\section{Acknowledgements}

Thanks are due to South Africa's national Department of Tourism for funding this review as part of a broader investigation on the planning and utilisation of caravan parks in the country. Useful inputs for revision of earlier drafts have been obtained from reviewer comments as well as the contributions made by Teddy, Dawn and Skye Norfolk.

\section{REFERENCES}

Al-Zahawai, M.I., Bilal, A.T. \& Al-Daloy, S.E. (2019). Activating and Managing Camping Tourism and Its Role in Increasing Tourist's Expenditure. Journal of University of Human Development, 5 (1), 44-6o.

Bigné, E. \& Decrop, A. (2019). Paradoxes of Postmodern Tourists and Innovation in Tourism Marketing. In E. Fayos-Sola \& C. Cooper (eds.), The Future of Tourism, Cham, Switzerland: Springer International, 131-154.

Blichfeldt, B.S. (2009). Innovation and Entrepreneurship in Tourism: The Case of a Danish Caravan Site. Pasos, 7 (3), $415-431$.

Blichfeldt, B.S. \& Mikkelsen, M.V. (2013). Vacability and Sociability as Touristic Attraction. Tourist Studies, 13 (3), 235-250.

Blichfeldt, B.S. \& Mikkelsen, M.V. (2014). Camping, Tourism. In J. Jafari \& H. Xiao (eds.), Encyclopedia of Tourism, (Living Edition), Dordrecht: Springer, 1-2.

Brochado, A. \& Brochado, F. (2019). What Makes a Glamping Experience Great? Journal of Hospitality and Tourism Technology, 10 (1), 15-27.

Brochado, A. \& Pereira, C. (2017). Comfortable Experiences in Nature Accommodation: Perceived Service Quality in Glamping. Journal of Outdoor Recreation and Tourism, 17, 77-83.

Brooker, E. \& Joppe, M. (2013). Trends in Camping and Outdoor Hospitality - An International Review. Journal of Outdoor Recreation and Tourism, 3-4, 1-6.

Brooker, E. \& Joppe, M. (2014). A Critical Review of Camping Research and Direction for Future Studies. Journal of Vacation Marketing, 20 (4), 335-351.

Budiasa, M., Suparta, K. \& Nurjaya, W. (2019). Implementation of Green Tourism Concept on Glamping Tourism in Bali. Advances in Social Science, Education and Humanities Research, 354, 210-214.

Bunce, D. (2010). Relocatable Homes: Medieval Tenure in the 21st century? Urban Policy and Research, 28 (3), $277-292$.

Caldicott, R. (2011). Supply-side Evolution of Caravanning in Australia: An Historical Analysis of Caravan Manufacturing and Caravan Parks. Lismore, NSW, Australia: School of Tourism and Hospitality, Southern Cross University.

Caldicott, R.W. \& Scherrer, P. (2013a). The Life Cycle of Caravan Parks in Australia: The Case of Northern New South Wales. Australian Geographer, 44 (1), 63-80.

Caldicott, R.W. \& Scherrer, P. (2013b). Facing Divergent Supply and Demand Trajectories in Australian Caravanning: Learnings From the Evolution of Caravan Park Site-mix Options in Tweed Shire. Journal of Vacation Marketing, 19 (2), 117-131.

Caldicott, R., Jenkins, J.M. \& Scherrer, P. (2018). Wherever I Park my RV, That's My Home. In C.M. Hall \& D. Müller (eds.), The Routledge Handbook of Second Home Tourism and Mobilities, Abingdon: Routledge.

Caldicott, R., Scherrer, P. \& Jenkins, J. (2014). Freedom Camping in Australia: Current Status, Key Stakeholders and Political Debate. Annals of Leisure Research, 17 (4), 417-442.

Cerović, Z. (2014). Innovative Management of Camping Accommodation. Horizons: International Scientific Journal Series A, 13, 55-68.

Collins, D. \& Kearns, R. (2010). Pulling Up the Tent Pegs?: The Significance and Changing Status of Coastal Campgrounds in New Zealand. Tourism Geographies, 12 (1), 53-76.

Collins, D., Bates, L., Kearns, R. \& Evans, J. (2020). Considering the Camp: Ambivalent Geographies of Mobile Dwelling. Applied Mobilities, 5 (1), 21-38.

Collins, D., Kearns, R., Bates, L. \& Serjeant, E. (2018). Police Power and Fettered Freedom: Regulating Coastal Freedom Camping in New Zealand. Social and Cultural Geography, 19 (7), 894-913.

Crabeck, S. (2013). Measuring the Supply of Tourism Accommodation: Figures that Make No Sense?: Reflections on Campsite Statistics for Wallonie (Belgium). Journal of Tourism History, 5 (2), 201-215.

Cvelić-Bonifačić, J., Milohnić, I. \& Cerović, Z. (2017). Glamping - Creative Accommodation in Camping Resorts: Insights and Opportunities. Tourism in Southern and Eastern Europe, 4, 101-114.

Dawson, S. (2007). Working-class Consumers and The Campaign for Holidays With Pay. Twentieth Century British History, 18 (3), 277-305.

Dawson, S. (2011). Holiday-Camps in Twentieth Century Britain: Packaging Pleasure. Manchester: Manchester University Press.

Del Moretto, D., Colla, V. \& Branca, T.A. (2017). Sustainable Mobility for Campsites: The Case of Maccia Lucchese. Renewable and Sustainable Energy Reviews, 68 (2), 1063-1075.

Doğantan, E. \& Emir, O. (2019). Determination of Trailer Park Criteria in Rural Areas. Journal of Tourism and Gastronomy Studies, 7 (4), 2383-2398.

Doğantan, E., Gűlenç, S. \& Kozak, N. (2017). The Evolution and Transformation of Camping and Coastal Campgrounds in Antalya, Turkey. Turizam, 65 (1), 75-85.

Ensor, L. (2013). 'Butlins-style' Resorts for Holidaying Poor. Business Day Live (Johannesburg), 15 May. 
Feigenbaum, A., Frenzel, F. \& McCurdy, P. (2013). Protest Camps. London: Zed.

Garcia-Pozo, A., Sanchez-Ollero, J.L., \& Marchante-Lara, D.M. (2011). Applying a Hedonic Model to the Analysis of Campsite Pricing in Spain. International Journal of Environmental Research, 5 (1), 11-22.

Garst, B.A., Williams, D.R. \& Roggenbuck, J.W. (2010). Exploring Early Twenty-first Century Developed Forest Camping Experiences and Meanings. Leisure Sciences, 32, 90-107.

Gilbert, H. (2013). The Loss of Low Cost Caravan Parks - Causes, Cases and Social Consequences. In K. Ruming, B. Randolph \& N. Gurran (eds.), Proceedings: State of Australian Cities Conference, 2013, Sydney: State of Australian Cities Research Network.

Goodall, B. (1987). Book Review: Goodnight Campers!: The History of the British Holiday Camp. The Town Planning Review, 58 (1), 95.

Gračan, D. \& Birin, A. (2013). The Implementation of Ecological Standards in Sustainable Development of Croatian Camps. Tourism in Southern and Eastern Europe, 2, 131-143.

Green, F.B. (1978). Recreational Vehicles: A Perspective. Annals of Tourism Research, 5 (4), 429-439.

Grzinic, J., Zarkovic, A. \& Zanketic, P. (2010). Positioning of Tourism in Central Dalmatia Through the Development of Camping Tourism. International Journal of Economic Perspectives, 4 (3), 525-535.

Hewer, M.J., Scott, D. \& Gough, W.A. (2015). Tourism Climatology for Camping; A Case Study of Two Ontario Parks (Canada). Theoretical and Applied Climatology, 121 (3-4), 401-411.

Holloway, D., Green, L. \& Holloway, D. (2011). The Intratourist gaze: Grey Nomads and 'Other Tourists'. Tourist Studies, 11(3), 235-252.

Hrgović, A-M.V., Cvelić-Bonifačić, J. \& Licul, I. (2018). Glamping - New Outdoor Accommodation. Ekonomska Misao I Praksa, 2, 621-639.

Hrgović, A-M.V., Cvelić-Bonifačić, J. \& Milohnić, I. (2019). Dimensions of Service Quality in Glamping. Tourism in Southern and Eastern Europe, 5, 773-785.

Janiskee, R.L. (1990). Resort Camping in America. Annals of Tourism Research, 17 (3), 385-407

Jayakody, J.A.D.C. (2017). Identification of Factors Affecting the Success of Caravan Tourism Industry in Sri Lanka. MBA thesis (Entrepreneurship), University of Moratuwa, Sri Lanka.

Jiminez, L.N. \& Martinez, O.F. (2017). Using GIS to Analyse the Camping Industry: The case of Mexico. In C. Lee, S. Filep, J.N. Albrecht \& W.J.L. Coetzee (eds.), CAUTHE 2017: Time for Big Ideas? Re-thinking the Field for Tomorrow. Dunedin: University of Otago, 687-691.

Kambic, K. (2018). Book Review: Heading out: A History of American Camping. Journal of Tourism History, 10 (3), $298-300$.

Kearns, R., Collins, D., Bates, L. \& Serjeant, E. (2019). Campgrounds as Service Hubs for the Marginally Housed. Geographical Research 57 (3), 299-311.

Ketter, E. (2020). Millennial Travel: Tourism Microtrends of European Generation Y. Journal of Tourism Futures. DOI 10.1108/JTF- 10-2019-0106

Lashley, C. (2015). Researching Snails on Holiday: An Agenda for Caravanning and Caravanners? Research in Hospitality Management, 5 (2), 115-122.

Lee, W.S., Lee, J-K., \& Moon, J. (2019). Influential Attributes for the Selection of Luxury Camping: A Mixedlogit Method. Journal of Hospitality and Tourism Management, 40, 88-93.

Liberato, P., Coelho, J. \& Liberato, D. (2020). Price Versus Service Assessment in Glamping. In V. Katsoni \& T. Spyraidis (eds.), Cultural and Tourism Innovation in the Digital Era. Cham, Switzerland: Springer Proceedings in Business \& Economics, 629-638.

Lucivero, M. (2012). Camping and Open-air Tourism: An Opportunity for Sustainable Tourism in Coastal Areas. In 6th Conference of the International Forum on Urbanism (IFoU) TOURBANISM, Barcelona. Delft: International Forum on Urbanism, 1-9.

Middleton, V.T.C. (2010). Sir William Edmund Heygate Colbourne (Billy) Butlin 1899-1980. In R. Butler \& R.A. Russell (eds.), Giants of Tourism. Wallingford: CABI Publishing, 32-44.

Mikkelsen, M.V. \& Blichfeldt, B.S. (2015). 'We Have Not Seen the Kids for Hours': The Case of Family Holidays and Free-range Children. Annals of Leisure Research, 18 (2), 252-271.

Mikkelsen, M.V. \& Blichfeldt, B.S (2018). Grand Parenting by the Pool. Young Consumers, 19 (2), 127-140.

Mikkelsen, M.V. \& Cohen, S.A. (2015). Freedom in Mundane Mobilities: Caravanning in Denmark. Tourism Geographies, 17 (5), 663-681.

Mikulić, J., Prebežac, D., Šerić, M., \& Krešić, D. (2017). Campsite Choice and the Camping Tourism Experience: Investigating Decisive Campsite Attributes Using Relevance-determinance Analysis. Tourism Management, 59, 226-233.

Milohnić, I. \& Cvelić-Bonifačić, J. (2015). Sustainable Camping Management: A Comparative Analysis Between Campsites and Hotels in Croatia. Tourism in Southern and Eastern Europe, 3, 211-222.

Milohnić, I., Cvelić-Bonifačić, J., \& Licul, I. (2019). Transformation of Camping into Glamping - Trends and Perspectives. Tourism in Southern and Eastern Europe, 5, 457-473.

Mthente Research and Consulting Services (2013). Towards Developing a Budget Travel Destination Chain in South Africa. Report prepared for the Industrial Development Corporation, Johannesburg.

Nelson, K. \& Minnery, J. (2008). Caravan Parks as Social Housing: The Tensions Between Public Goals and Private Interests in Brisbane, Australia. Planning Practice \& Research, 23 (4), 479-494. 
Nunkoo, R., Smith, S.L.J. \& Ramkissoon, H. (2013). Residents' Attitudes to Tourism: A Longitudinal Study of 140 Articles from 1984 to 2010. Journal of Sustainable Tourism, 21, 5-25.

O'Dell, S. (2015). Post-war Tourism in the Tendring District and Beyond: The Rise of the Holiday Caravan Park, c 1938-1989. PhD Dissertation, University of Essex.

O’Neill, M.A., Riscinto-Kozub, K.A. \& Van Hyfte, M. (2010). Defining Visitor Satisfaction in the Context of Camping Oriented Nature-based Tourism: The Driving Force of Quality. Journal of Vacation Marketing, 16 (2), 141-156.

Okumus, F., Köseoglu, M.A.,Putra, E.D., Yildiz, M. \& Dogan, I.C. (2019). Conceptual Structure of Lodgingcontext Studies: 1990-2016. Journal of Hospitality \& Tourism Research, 43 (2), 210-225.

Østby, P. (2013). Car Mobility and Camping Tourism in Norway, 1950-1970. Journal of Tourism History, 5 (3), $287-304$.

Park, J., Ellis, G., Kim, S.S. \& Prideaux, B. (2010). An Investigation of Perceptions of Social Equity and Price Acceptability Judgments for Campers in the U.S. National Forest. Tourism Management, 31, 202-212.

Patterson, I., Pegg, S. \& Mahedevan, R. (2015). The Benefits of Short Stay Caravan Travel Based on the Lived Experiences of Grey Caravanners in Australia. Tourism Analysis, 20 (5), 539-549.

Persic, M., Jankovic, S. \& Cvelić-Bonifačić, J. (2017). Integrated Reporting As a Trend and Challenge for Benchmarking and Competitiveness of the Camping Business. Tourism in Southern and Eastern Europe, 4, 451-468.

Petrusa \& Vlahov, A. (2019). The Role of Glamping in Development of Camping Tourism Offer - Possibilities and Future Prospects in the Republic of Croatia. In J. Simurina, I.N. Braje \& I Pavic (eds.), Proceedings of FEB Zagreb 1oth International Odyssey Conference on Economics and Business 12-15 June Opatija, Croatia. Zagreb: University of Zagreb Faculty of Economics \& Business, 826-843.

Poldrugovac, K., Jankovic, S. \& Persic, M. (2019). The Significance of Competitive Pricing and Revenue Management in Camping. International Journal of Revenue Management, 11 (1-2), 76-88.

Prentice, R.C. \& Witt, S. F. (1991). Holiday Parks: Current Issues and Trends. International Journal of Hospitality Management, 10 (3), 229-244.

Prideaux, B. (2020). Drive and Car Tourism: A Perspective Article. Tourism Review, 75 (1), 109-112.

Prideaux, B. \& McClymont, H. (2006). The Changing Profile of Caravanners in Australia. International Journal of Tourism Research, 8, 45-58.

Rees Pryce, W.T. (1967). The Location and Growth of Holiday Caravan Camps in Wales, 1956-65. Transactions of the Institute of British Geographers, 42, 127-152.

Rice, W.L., Park, S.Y., Pan, B. \& Newman, P. (2019). Forecasting Campground Demand in US National Parks. Annals of Tourism Research, 79, 424-438.

Rogerson, C.M. (2015). Restructuring the Geography of Domestic Tourism in South Africa. Bulletin of Geography: Socio-Economic Series, 29, 119-135.

Rogerson, C.M. \& Rogerson, J.M. (2019). Tourism, Local Economic Development and Inclusion: Evidence from Overstrand Local Municipality, South Africa. GeoJournal of Tourism and Geosites, 25 (2), 293-308.

Rogerson, C.M. \& Rogerson, J.M. (2020). Coastal Tourism in South Africa: A Geographical Perspective. In J.M. Rogerson \& G. Visser (eds.), New Directions in South African Tourism Geographies. Cham, Switzerland: Springer International, 227-247.

Sakacova, K.L. (2013). Glamping - Nature Served on a Silver Platter. Masters thesis, Aalborg, Aalborg University, Denmark.

Salo, A., Teixidor, A., Fluvia, M. \& Garriga, A. (2020). The Effect of Different Characteristics on Campsite Pricing: Seasonality, Dimension and Location Effects in a Mature Destination. Journal of Outdoor Recreation and Tourism, 29, 100263

Simeoni, F. \& Cassia, F. (2019). From Vehicle Suppliers to Co-creators in Tourism: The Evolving Role of Italian Motorhome Manufacturers. Current Issues in Tourism, 22 (2), 218-236.

Stephens, K.T., Leonard, M.J. \& Smolder, D.L. (1989). Camping Tourism in the Smoky Mountains. Tourism Management, 10 (1), 66-69.

Timothy, D. J., \& Teye, V. B. (2009). Tourism and the Lodging Sector. London: Butterworth-Heinemann.

Triantafillidou, A. \& Siomkos, G. (2013). Summer Camping: An Extraordinary Nostalgic, and Interpersonal Experience. Journal of Vacation Marketing, 19 (3), 197-208.

Van Heerden, C.H. (2008). Leisure Motorhoming: The Case of the Motorhome Club of South Africa. South African Journal for Research in Sport, Physical Education and Recreation, 30 (1), 125-136.

Van Heerden, C.H. (2010a). Self Drive Tourism in South Africa With Specific Emphasis on Caravanning. In B. Prideaux \& D. Carson (eds.), Drive Tourism: Trends and Emerging Markets. London: Routledge, 85-97.

Van Heerden, C. H. (2010b). An Exploratory Analysis of Leisure Caravanning in the Kruger National Park in South Africa. Innovative Marketing, 6 (1), 66-72

Van Heerden, C. H. (2020). Motivation and Involvement in Camping - A Gender Perspective. African Journal of Hospitality, Tourism and Leisure, 9 (1), 1-14.

Van Rooij, N. \& Margaryan, L. (2020). Integration of "Ideal Migrants": Dutch Lifestyle Expat-reneurs in Swedish Campgrounds. Rural Society. DOI. 10.1080/10371656.2020.1718329.

Ward, C. \& Hardy, D. (1986). Goodnight Campers!: The History of the British Holiday Camp, London: Mansell. Young, T. (2017). Heading Out: A History of American Camping. Ithaca: Cornell University Press.

Submitted:

26.11.2019
Revised:

03.03.2020
Accepted and published online 09.03.2020 